Janusz Szymański

Uniwersytet w Białymstoku

e-mail: janusz_szymanski@interia.eu

\title{
Klauzula rebus sic stantibus w prawie traktatów z perspektywy historycznej
}

\begin{abstract}
SUMMARY
The Rebus sic stantibus Clause in the Law of Treaties from a Historical Perspective

The clause of rebus sic stantibus is a principle in customary international law providing that where there has been a fundamental change of circumstances since an agreement was concluded, a party to that agreement may withdraw from or terminate it. It is justified by the fact that some treaties may remain in force for long periods of time, during which fundamental changes might have occurred. Such changes might encourage one of the parties to adopt drastic measures in the face of general refusal to accept an alteration in the terms of the treaty. However, this doctrine has been criticized on the grounds that, having regard to the absence of any system for compulsory jurisdiction in the international law, it could operate as a discrupting influence upon the binding force of obligations undertaken by states. It might be used to justify withdrawal from treaties on rather tenuous grounds.

The modern approach is to admit the existence of the doctrine, but severely restrict its scope. The International Court in the Fisheries Jurisdiction case declared that: "[i]nternational law admits that a fundamental change in the circumstances which determined the parties to accept a treaty, if it has resulted in a radical transformation of the extent of the obligations imposed by it, may, under certain conditions, afford the party affected a ground for invoking the termination or suspension of the treaty".

Before the doctrine may be applied, the Court continued, it is necessary that such changes "must have increased the burden of the obligations to be executed to the extent of rendering the performance something essentially different from the originally undertaken".

The doctrine of rebus sic stantibus was examined in the Gabcikovo-Nagymaros Project case too, where the International Court concluded that: "The changed circumstances advanced by Hungary are, in the Court's View, not of such a nature, either individually or collectively, that their effect what radically transform the extent of the obligations still to be performed in order to accomplish the Project. A fundamental change of
\end{abstract}


circumstances must have been unforeseen; the existence of the circumstances at the time of the Treaty's conclusion must have constituted an essential basis of the consent of the parties to be bound by the Treaty. The negative and conditional wording of article 62 of the Vienna Convention on the Law of Treaties is a clear indication moreover that the stability of treaty relations requires that the plea of fundamental change of circumstances should be applied only in exceptional cases".

Key words: treaty, clause of rebus sic stantibus, fundamental change of circumstances, the termination of treaty.

\section{Geneza i kształtowanie się klauzuli rebus sic stantibus w ujęciu historycznym}

Kwestia wpływu zmiany okoliczności na obowiązywanie relacji traktatowych między państwami ma bardzo długą historię. Sięga bowiem początków stosunków międzynarodowych i stanowi od dawna punkt budzący zainteresowanie i dyskusje wielu znawców prawa międzynarodowego. Przez długi czas dość wyraźnie wykorzystywano zasadniczą zmianę okoliczności jako wytłumaczenie dla różnego rodzaju posunięć, również tych siłowych, w relacjach między państwami. Tak więc z upływem lat klauzula ta zjednała sobie zarówno wielu zagorzałych zwolenników, jak i gorących przeciwników. Jak spostrzegł A. Brzozowski, pochodzenie klauzuli rebus sic stantibus (dalej: RSS) jest kwestią dyskusyjną. Niektórzy autorzy upatrują jej zalążków w glosach cywilnych z czasów średniowiecza, inni - w glosach kanonicznych, kolejni zaś w dziełach filozofów ${ }^{1}$.

Już w starożytności zwrócono uwagę na istotę zmiany okoliczności oraz skutki, jakie pociąga za sobą transformacja istniejących warunków. W dorobku literackim słynnego polityka i mówcy rzymskiego Cycerona doszukać się możemy przykładów, gdy w obliczu istotnej zmiany okoliczności można domagać się odejścia od obowiązku wykonania zobowiązań. Twierdził on, iż w pewnych sytuacjach, kiedy pod wpływem okoliczności zmianie ulegają podstawowe wymogi sprawiedliwości, zmieniają się również zobowiązania².

Choć powszechnie uważa się, iż doktryna ta nie była jeszcze znana w czasach rozwoju prawa rzymskiego, jak miało to miejsce w przypadku zasady pacta sunt servanda, to jednak nie wszyscy przedstawiciele nauki prawa międzynarodowego są co do tego zgodni. Kwestię tę podejmowali w swoich publikacjach poświęconych temu zagadnieniu chociażby H. F. Koeck czy G. Haraszti³. Na gruncie starożytnego rzymskiego prawa prywatnego trudno doszukiwać

1 A. Brzozowski, Wpływ zmiany okoliczności na zobowiązania w prawie polskim (na tle prawa niektórych państw obcych), Warszawa 1992, s. 17.

2 M. T. Cicero, Pisma filozoficzne, t. 2, Warszawa 1960.

3 S. Sawicki, T. Kamiński, Clausula rebus sic stantibus a zasadnicza zmiana okoliczności jako przestanka 
się wyrażonej wprost idei zasadniczej zmiany okoliczności. Jednakże $\mathrm{w}$ tekstach niektórych prawników rzymskich z tamtego okresu możemy odnaleźć nawiązania do koncepcji RSS w ujęciu cywilnoprawnym ${ }^{4}$.

W czasach epoki średniowiecza, obok rozkwitu teorii zasadniczej zmiany okoliczności $\mathrm{w}$ prawie prywatnym, pojawia się termin rebus sic stantibus. Za jego twórcę uznaje się André Tiraqueau - francuskiego prawnika z połowy XVI w. Jednakże istnieje też odmienna teoria, mówiąca o tym, iż termin rebus sic stantibus znany był już wcześniej, około XII w. Z pojęciem tym wiąże się postać Pilliusa - glosatora działającego na Półwyspie Apenińskim, miejscu, gdzie znajdowały się wówczas sławne uniwersytety ${ }^{5}$. Początkowo pojęcie to funkcjonowało niesamodzielnie, obok innych sformułowań odnoszących się do zmiany okoliczności, z czasem jednak wyparło inne i stało się powszechnie stosowane. Potwierdzenia treści klauzuli poszukiwano również w licznych źródłach i zasadach prawa rzymskiego, choć w tamtym czasie pojęcie to nie było jeszcze dobrze znane. W miarę rozwoju klauzuli RSS zaczęto więc dokonywać prób jej zdefiniowania. $Z$ początku ujmowano ją jako dowolny stosunek prawny (lub ogólnie „wszystko”), który może wygasnąć bądź ulec zmianie, jeżeli zmiana stosunków, która nastąpiła, tego wymaga ${ }^{6}$. Wkrótce potem, na przełomie XV i XVI w. koncepcja rebus sic stantibus stała się uniwersalną koncepcją prawa prywatnego, odnoszącą się do milczącego zastrzeżenia niezmienności pierwotnych warunków ${ }^{7}$.

Również w epoce renesansu, jak zauważa to T. Jasudowicz, możemy odnaleźć poglądy, które wywarły wpływ na dalsze kształtowanie się teorii zasadniczej zmiany okoliczności i związanej z nią praktyki państw. Przywołuje on przykład opinii Machiavellego, który twierdził, iż władca winien kierować się okolicznościami i zmianami losu, obowiązek przestrzegania umowy ustaje zaś wówczas, gdy przyczyny zawarcia traktatu wygasły lub uległy znacznej zmianie, a dotrzymanie tejże umowy zwróciłoby się przeciwko władcy. Jako inny ważny przykład wspomniany autor przytacza praktykę kolejnych papieży. Często zwalniali oni katolickich władców z dotrzymania przysiąg czy zobowiązań zawartych z innowiercami bądź heretykami, tłumacząc to względami zmienio-

wygaśnięcia traktatu w świetle Konwencji Wiedeńskiej z 1969 roku, [w:] Consul est iuris et patriae defensor. Ksiegga pamiatkowa dedykowana doktorowi Andrzejowi Kremerowi, red. F. Longchamps de Bérier, R. Sarkowicz, M. Szpunar, Warszawa: Ministerstwo Spraw Zagranicznych. Biuro Archiwum i Zarządzania Informacją, 2012, s. 355.

4 T. Jasudowicz, Wplyw zmiany okoliczności na obowiązywanie umów międzynarodowych, Toruń 1977, s. 31.

5 K. Przybyłowski, Klauzula "rebus sic stantibus” w rozwoju historycznym, „Pamiętnik Historyczno-Prawny", Lwów 1926, t. 3, z. 1.

6 Idem, Clausula rebus sic stantibus, [w:] Encyklopedja podręczna prawa prywatnego, red. H. Konic, Warszawa 1930-1935, s. 125.

7 Idem, Klauzula "rebus sic stantibus"... 
nych okoliczności. Niejednokrotnie podobnymi powodami motywowano odrzucenie anachronicznych czy wręcz niewygodnych konkordatów ${ }^{8}$.

Wśród myśli i doktryn filozoficznych z przeszłości także możemy odnaleźć pewne odwołania do faktu zmiany okoliczności i jego wpływu na zobowiązania umowne, które w obliczu takich okoliczności mogą ulec wygaśnięciu. Spinoza twierdził, że obowiązek wykonywania traktatu trwa tak długo, jak powód, dla którego został on zawarty, i nie dłużej', a umowę zawiera się na czas przyszły tylko, gdy istnieje domniemanie, że okoliczności nie ulegną zmianie. Jeżeli jednak tak się stanie, wówczas „zmienia się podstawa całego stanu rzeczy"10. Thomas Hobbes uznawał natomiast, że „umowa jest bezskuteczna, jeżeli powstaje zasadna wątpliwość, czy druga strona ją wykona”, a „przyczyną obawy, która umowę taką czyni bezskuteczną, musi być zawsze coś, co zjawia się dopiero wtedy, gdy ugoda jest już zawarta; taką przyczyną może być jakiś nowy fakt albo inny znak"11.

Wiek XVIII przyniósł falę krytyki klauzuli zasadniczej zmiany okoliczności w dziedzinie prawa. Obawiano się bowiem nieuzasadnionych nadużyć, sądzono również, iż stanowi ona istotne naruszenie zasad bezpieczeństwa obrotu prawnego. Dlatego też w kolejnym, XIX w., przy zmianie okoliczności, jakie nastąpiły od czasu wykonania zobowiązania, bardziej odnoszono się do zasady pacta sunt servanda ${ }^{12}$. Na gruncie nauki prawa narodów najczęściej wspomina się istotną rolę przedstawicieli doktryny, do których należeli przede wszystkim: E. de Vattel, H. Grocjusz czy A. Gentilis. Ich stanowiska wobec podejmowanego zagadnienia wywarły ogromny wpływ na późniejszą praktykę traktatową państw. Ostatni ze wspomnianych autorów dopuszcza wyjątek odstąpienia od wykonania zobowiązań wynikających z traktatu, motywując to „nowymi warunkami”, „nowym rozwojem” bądź też sytuacją pojawienia się sprzeczności z "naturalną racją". I tak A. Gentilis zakładał, że w przypadku wszystkich aktów prawnych występuje , „[...] wyjątek dotyczący zmiany stanu rzeczy, jeżeli zmiany nie można było przewidzieć. Nawet gdy przysięga jest dołączona, wchodzi w grę dorozumiane zastrzeżenie, jeżeli stosunki pozostaną w tym samym stanie"13. Z kolei H. Grocjusz, z jednej strony był przeciwny powoływaniu się na zmianę okoliczności, jako przesłankę zwolnienia się od zobowiązań wynikających z traktatu, z drugiej zaś dopuszczał taką możliwość, pod warunkiem że „,[...] byłoby rzeczą najbardziej oczywistą, iż

\footnotetext{
T. Jasudowicz, op. cit., s. 32-33.

F. Pollock, Spinoza. His Life and Philosophy, New York 1989, s. 307.

10 T. Jasudowicz, op. cit., s. 33.

11 Ibidem

12 R. Jastrzębski, Geneza i znaczenie klauzuli "rebus sic stantibus” w polskim prawie prywatnym, Łódź 2010.

13 A. Gentilis, De jure belli Libii tres, tłum. J. C. Rolfe, Oxford 1933, s. 385.
} 
jedyna racja [...] obejmuje obecny stan rzeczy"14. Tym samym H. Grocjusz uznawał możliwość zastosowania klauzuli zasadniczej zmiany okoliczności, jednakże w bardzo ograniczonym zakresie i tylko wtedy, kiedy warunek niezmienności okoliczności był oczywisty lub jednoznacznie wskazany w treści przyrzeczenia ${ }^{15}$.

Zwolennikiem koncepcji zmiany okoliczności był również wspomniany już szwajcarski prawnik, filozof i dyplomata E. de Vattel. Według niego ,,jeżeli jest pewne i jasne, że przyrzeczenie było dane wobec czy na skutek istniejącego stanu rzeczy $w$ tymże stanie; to jest oczywiste, ponieważ przyrzekający zobowiązał się tylko dlatego, że wychodził z takiego założenia. Kiedy więc stan rzeczy istotny dla przyrzeczenia, stan rzeczy, bez którego przyrzeczenie nie zostałoby dane, zmienia się, przyrzeczenie upada wraz ze swą podstawą"16. Natomiast E. de Vattel zaznaczał przy tym również, iż stosowanie omawianej klauzuli może skutkować nadużyciami, należy więc powoływać się na zaistniałą zmianę okoliczności w sposób jak najbardziej racjonalny i wedle uzasadnionych przesłanek ${ }^{17}$.

Trzeba także wspomnieć o przypadkach zastosowania przez państwa klauzuli RSS w praktyce, choć faktycznie do połowy XIX w. nie było ich wiele. Najgłośniejszym i najczęściej przywoływanym przez autorów przykładem jest wydarzenie z 1585 r. Królowa Anglii Elżbieta I, powołując się wówczas na zaistniałą zmianę okoliczności, domagała się unieważnienia zobowiązań dotyczących subsydiów i pomocy wojskowej zaciągniętych wobec Stanów Holenderskich. Swoje żądanie motywowała stwierdzeniem, iż konwencje winny obowiązywać tylko do momentu, gdy stan rzeczy nie ulegnie zmianie ${ }^{18}$. Inną sytuację wykorzystania klauzuli przywołuje T. Jasudowicz. W 1741 r. pruski król Fryderyk II zawarł z Wrocławiem traktat o neutralności, w którym umieszczono zastrzeżenie mówiące, iż jego postanowienia będą obowiązywały jedynie do czasu, aż okoliczności istniejące $\mathrm{w}$ momencie zawierania umowy nie ulegną zmianie $^{19}$.

Przykłady zastosowania klauzuli RSS w praktyce państw stają się liczniejsze dopiero od drugiej połowy XIX w. Być może wpływ na to miał rozwijający się pozytywizm prawniczy oraz narastająca potrzeba wyjaśnienia i głębszego przyjrzenia się kwestiom wypowiedzenia czy wygaśnięcia umowy między-

14 H. Grotius, Trzy księgi o prawie wojny i pokoju, w których znajduja wyjaśnienie Prawa Natury i Prawo Narodów, a także główne zasady prawa publicznego, tłum. R. Bierzanek, t. 1, Warszawa 1957, s. 561.

15 S. Sawicki, T. Kamiński, op. cit., s. 356.

16 E. de Vattel, Prawo Narodów, czyli zasady prawa naturalnego zastosowane do postępowania $i$ spraw narodów i monarchów, tłum. B. Winiarski, t. 1, Warszawa 1958, s. 553.

17 Ibidem, s. 553 i nast.

18 S. Sawicki, T. Kamiński, op. cit., s. 358.

19 T. Jasudowicz, op. cit., s. 34. 
narodowej ${ }^{20}$. Niemniej jednak, wyraźnie znaczące dla rozwoju klauzuli były zarówno źródła pochodzenia filozoficznego i politologicznego, jak i praktyka wielu państw. Analizując przypadki powołania się na zasadniczą zmianę okoliczności, zauważamy, iż w szeregu sytuacji norma ta była zdecydowanie nadużywana i niejednokrotnie wykorzystywana do uwolnienia się od kłopotliwych powinności wynikających z zawartych wcześniej umów między państwami. Rzutuje to na dzisiejszy, nieco ograniczony w stosunku do przeszłości, kształt klauzuli rebus sic stantibus nadany przez Konwencję wiedeńską o prawie traktatów, podpisaną 23 maja $1969 \mathrm{r}$.

\section{Rebus sic stantibus - ogólna zasada prawa, norma zwyczajowa czy konwencyjna?}

Jak dowodzi historia i praktyka obrotu traktatowego państw na przestrzeni wieków, klarowny wydaje się fakt, iż uregulowanie w prawie traktatów wpływu zasadniczej zmiany okoliczności na zobowiązania traktatowe stało się kwestią niezbędną i konieczną. Nieodzowne więc było powołanie do życia określonej normy prawnej odnoszącej się do wspomnianego zagadnienia. Normę tę zaczęto zatem określać mianem rebus sic stantibus. Jednakże z czasem zaistniał problem odpowiedniej klasyfikacji (czy raczej kwalifikacji jej charakteru) wspomnianej normy zwłaszcza w systemie źródeł (i norm) prawa międzynarodowego. Problem ten jest o tyle istotny, iż dotyczy kwestii zbadania podstaw obowiązywania klauzuli rebus sic stantibus w prawie międzynarodowym, odnosząc się do ogólnych jego zasad, zwyczaju międzynarodowego oraz prawa traktatowego.

W doktrynie prawa międzynarodowego znajdziemy wielu autorów uznających normę RSS jako ogólną zasadę prawa, w rozumieniu art. 38 pkt 1 lit. C Statutu Międzynarodowego Trybunału Sprawiedliwości ${ }^{21}$. Traktują oni fakt obowiązywania danej normy $w$ wewnętrznych systemach prawnych jako przesłankę dla istnienia podobnej normy w prawie międzynarodowym, z tym, że została ona dostosowana do właściwości stosunków międzynarodowych ${ }^{22}$.

Reprezentantem takich poglądów jest m.in. H. Lauterpacht. Traktuje on regułę odnoszącą się do zasadniczej zmiany okoliczności jako ogólną zasadę prawa, motywując swój pogląd tym, iż wywodzi się ona $\mathrm{z}$ ciągu innych norm czy instytucji prawa prywatnego $\mathrm{z}$ okresu rzymskiego, jak też $\mathrm{z}$ teraźniejszego prawa cywilnego ukształtowanego na poziomie poszczególnych

K. Przybyłowski, Klauzula „rebus sic stantibus"..., s. 357.

21 Statut Międzynarodowego Trybunału Sprawiedliwości, Dz. U. 1947.23.90.

22

T. Jasudowicz, op. cit., s. 38. 
państw ${ }^{23}$. Także H. W. Shawcross wywodzi istnienie klauzuli RSS m.in. $z$ angielskiej doktryny "frustration of contract" (udaremnienie, zniweczenie umowy), jak również innych norm prawa wewnętrznego ${ }^{24}$. Podobne stanowisko prezentuje chociażby R. Pal czy też Ch. Rousseau, który szczególnie podkreśla, iż nie chodzi o mechaniczne czy dosłowne przeniesienie klauzuli do dziedziny prawa międzynarodowego ${ }^{25}$.

Badając kwestię umiejscowienia reguły rebus sic stantibus $\mathrm{w}$ prawie międzynarodowym jako ogólnej zasady prawa międzynarodowego, w doktrynie równie często nawiązywano do rzymskiego prawa prywatnego, prawa kanonicznego, analogii z prawa angielskiego, uregulowań francuskiego kodeksu cywilnego oraz teorii imprévision czy też niemieckiego kodeksu cywilnego (BGB) i konkretnych przypadków wywodzących się z tamtejszego orzecznictwa ${ }^{26}$. Unormowania podobne $\mathrm{w}$ swych założeniach do klauzuli rebus sic stantibus znajdują się również w prawodawstwie innych państw, w szczególności w kodeksach zobowiązań oraz kodeksach cywilnych. Przyglądając się prawu polskiemu, tu także doszukać się możemy postanowień stanowiących wyraz koncepcji RSS. Zanim do polskiego porządku prawnego wszedł kodeks cywilny z 1964 r. $^{27}$ obowiązujący obecnie, reguła rebus sic stantibus regulowana była w art. 269 Kodeksu zobowiązań. Stanowił on, co następuje: „Gdyby z powodu nadzwyczajnych wypadków, jako to: wojny, zarazy, zupełnego nieurodzaju i innych klęsk żywiołowych, świadczenie było połączone z nadmiernymi trudnościami lub groziło jednej ze stron rażącą stratą, czego strony nie mogły przewidzieć przy zawarciu umowy, sąd może, jeżeli uzna to za konieczne według zasad dobrej wiary, po rozważeniu interesów obu stron, oznaczyć sposób wykonania, wysokość świadczenia lub nawet rozwiązać umowę"28. Przepis ten pozwalał sądom na rozwiązanie umowy, biorąc pod uwagę interes stron oraz zasadę dobrej wiary ${ }^{29}$. W pracach nad obecnie obowiązującym kodeksem cywilnym zamierzano początkowo wprowadzić przepis opierający się na art. 269 Kodeksu zobowiązań z 1933 r., ostatecznie tak się jednak nie stało. Dopiero w 1990 r., w związku z nowelizacją kodeksu cywilnego, przywrócono klauzulę RSS, umieszczając regulację w postaci art. $357^{1}$ i $358^{1} \S 3^{30}$.

23 F. Wharton, Commentaries on American Law, Philadelphia 1886, s. 161.

24 L. Ehrlich, Prawo międzynarodowe, wyd. 4, Warszawa 1958, s. 304.

25 T. Jasudowicz, op. cit., s. 39.

26 Ibidem, s. 39-40.

27 Dz. U. Nr 16, poz. 93, z późn. zm.

28 Dz. U. Nr 82, poz. 598. Rozporządzenie Prezydenta Rzeczypospolitej z dnia 27 października 1933 r. - Kodeks zobowiązań.

29 L. Domański, Instytucje kodeksu zobowiąań. Komentarz teoretyczno-praktyczny. Część ogólna, Warszawa 1936, s. 903-904.

30 R. Jastrzębski, op. cit., s. 162-164. 
Jak widać, w systemach prawa wewnętrznego państw, w tym także Polski, możemy odnaleźć uregulowania odnoszące się do zasadniczej zmiany okoliczności, która skutkować może zmianą postanowień umownych lub też ich wygaśnięciem. Nie przesądza to jednak o obowiązywaniu tejże normy jako normy prawa międzynarodowego. Można natomiast wysunąć pogląd, iż stanowi ona swoisty dowód na kształtowanie się zasadniczej zmiany okoliczności jako normy zwyczajowej, albowiem państwa na płaszczyźnie międzynarodowej odwoływały się w swej praktyce do analogicznych norm znajdujących się $\mathrm{w}$ prawie wewnętrznym ${ }^{31}$.

Zanim jednak przejdę do rozważenia problemu w świetle norm zwyczajowych, należy pokrótce zbadać miejsce klauzuli rebus sic stantibus w międzynarodowym prawie konwencyjnym. Można zaobserwować, iż na przestrzeni lat zdarzały się przypadki bezpośredniego jej wprowadzenia do treści umowy jako ogólnej normy czy też szczegółowych klauzul odnoszących się do zaistnienia nowych warunków, które mogłyby wpłynąć na obowiązywanie i stosowanie zobowiązań traktatowych, jak również zbieżnych rozwiązań konwencyjnych wprowadzanych z myślą o zmieniających się warunkach. Jedną z takich kodyfikacji zawierających próbę wprowadzenia normy RSS do systemu norm konwencyjnych była hawańska konwencja o prawie traktatów z 1928 r., którą jednak ratyfikowała tylko nieznaczna część państw spośród tych, które ją podpisały. W rezultacie konwencja ta nie weszła nigdy w życie. Wobec tego, w późniejszym czasie, podobnej próby podjęła się Komisja Prawa Międzynarodowego ONZ. Podczas prac nad projektem kodyfikacji prawa traktatów poświęcono również szczególną uwagę analizie problemu doktryny rebus sic stantibus. Niezwykle ważnym dokumentarnym dowodem są sprawozdania z obrad i sesji. Ostatecznie regulację o „zasadniczej zmianie okoliczności" umieszczono w części V Konwencji odnośnie do nieważności, wygaśnięcia i zawieszenia stosowania traktatów. Tym samym było to pierwsze unormowanie zagadnienia zmiany okoliczności oraz jej wpływu na obowiązywanie traktatów w powszechnym międzynarodowym prawie konwencyjnym. Mimo wszystko, zdaniem T. Jasudowicza, wspomniane przesłanki nie przesądzają w pełni o obowiązywaniu normy RSS na gruncie konwencyjnego prawa międzynarodowego ${ }^{32}$. Wydaje się, że wejście w życie Konwencji wiedeńskiej daje asumpt do zupełnie odmiennej oceny.

Pozostaje również rozważyć kwestię wpływu zmiany okoliczności na obowiązywanie postanowień traktatowych z punktu widzenia prawa zwyczajowego. Do stwierdzenia tego stanu rzeczy należy przede wszystkim wziąć pod uwagę obecność wystarczająco powszechnej i długotrwałej praktyki państw $\mathrm{w}$ relacjach traktatowych, a następnie jej uznania i wpływu na obowiązu-

31 T. Jasudowicz, op. cit., s. 41-44.

32 Ibidem, s. 44-54. 
jące prawo, za zwyczaj bowiem uznaje się tradycyjny, długotrwały, przyjęty powszechnie sposób postępowania w jakichś okolicznościach ${ }^{33}$. Jednakże, jak zauważa M. Frankowska, rozgraniczenie norm o charakterze kodyfikującym prawo traktatów i stanowiącym rozwój tego prawa okazuje się niemałym problemem. Zacierają się bowiem granice, uwidaczniając przy tym przewagę prawa zwyczajowego. Zdaniem autorki, istnienie w Konwencji danej normy stanowi już dostateczny i jasny dowód na istnienie analogicznej normy w prawie zwyczajowym ${ }^{34}$. Czy to twierdzenie sprawdza się także w przypadku normy rebus sic stantibus?

Analizując praktykę państw, znajdujemy potwierdzenie dla wyżej wspomnianej tezy. T. Jasudowicz w swojej pracy wskazuje liczne przykłady w stosunkach międzynarodowych powoływania się na zmianę okoliczności jako przesłankę do podważenia zobowiązań wynikających z traktatu. Wśród wielu przykładów omawianych chronologicznie, wskazuje m.in. przypadek Francji z 1848 r., kiedy to tamtejszy tymczasowy rząd wypowiedział część postanowień traktatów zawartych w 1815 r. odnośnie do zakazu fortyfikowania Hunningen, tłumacząc tę decyzję zaistnieniem istotnych zmian okoliczności, szczególnie zmianami wewnętrznymi w państwie francuskim. Jako inny przykład autor przywołuje decyzję Polski, która odmówiła jakiejkolwiek współpracy z organami międzynarodowymi przy kontroli stosowania systemu ochrony mniejszości, co było sprzeczne z postanowieniami tzw. małego traktatu wersalskiego. Stwierdzono jednak, że zobowiązania traktatu wygasły w związku z wprowadzeniem nowej konstytucji, licznych ustaw i innych aktów, a system ochrony mniejszości uznano za niedojrzały. Kolejny z przykładów - w 1938 r. Szwajcaria zażądała zmiany zobowiązań będących konsekwencją jej członkostwa w Lidze Narodów, motywując swój krok tym, iż powody, którymi kierowała się, wstępując do organizacji, już nie istnieją, ponieważ istotnie zmieniły się warunki ${ }^{35}$.

W tym miejscu należy także wspomnieć o stanowisku w sprawie klauzuli RSS wielu państw, które zabrały głos podczas prac kodyfikacyjnych nad Konwencją wiedeńską. Zdecydowana większość z nich opowiedziała się za uznaniem obowiązującego charakteru normy rebus sic stantibus. W opozycji pozostały m.in. Stany Zjednoczone, które miały wątpliwość co do słuszności umieszczania omawianej normy w Konwencji o prawie traktatów, pomimo faktu, iż w przeszłości często wykorzystywały klauzulę RSS ${ }^{36}$. Finalnie, KPM przy kodyfikacji prawa traktatów dość wyraźnie odcięła się od praktyki

33 J. Barcik, T. Srogosz, Prawo międzynarodowe publiczne, Warszawa 2008, s. 111.

34 M. Frankowska, Konwencja wiedeńska o prawie traktatów z perspektywy 40-lecia, [w:] 40 lat minęło praktyka i perspektywy Konwencji Wiedeńskiej o prawie traktatów, Warszawa 2009, s. 32-34.

35 T. Jasudowicz, op. cit., s. 55-78.

36 Ibidem, s. 80-81. 
państw, by stworzyć regułę dogodną i akceptowalną przez zainteresowane państwa $^{37}$. Zwyczajowy charakter omawianej normy w 1973 r. potwierdził MTS. W sporze dotyczącym rybołówstwa między Wielką Brytanią a Islandią doszedł do wniosku, iż art. 62 Konwencji, mówiący o zasadniczej zmianie okoliczności, może być uważany za kodyfikację prawa zwyczajowego w zakresie wygaśnięcia traktatu ${ }^{38}$.

Jak wynika z długotrwałej i powszechnej praktyki państw w prawie międzynarodowym, reguła RSS została przyjęta i stała się normą obowiązującą w prawie zwyczajowym. Dowodzą tego także prezentowane na forum Komisji Prawa Międzynarodowego stanowiska poszczególnych państw oraz opinia Międzynarodowego Trybunału Sprawiedliwości wyrażona w orzeczeniu z 1973 r. Przykład normy RSS stanowi zatem potwierdzenie tezy, iż Konwencja o prawie traktatów z 1969 r. jest swego rodzaju kodeksem zwyczajowego prawa traktatów.

\section{Rebus sic stantibus a zasada pacta sunt servanda}

Podejmując analizę normy rebus sic stantibus jako przesłanki wygaśnięcia umowy międzynarodowej, dość szybko natrafiamy na swego rodzaju zderzenie dwóch przeciwnych tendencji, a mianowicie: dynamiki rozwoju stosunków międzynarodowych oraz stabilności tychże stosunków, wyrażonych przy pomocy zasady pacta sunt servanda ${ }^{39}$. Elementem koniecznym wydaje się zatem zbadanie relacji pomiędzy wspomnianymi zasadami oraz odpowiedź na pytanie: czy norma RSS stanowi zaprzeczenie zasady „świętości” umów (pacta sunt servanda)?

Zasada pacta sunt servanda stanowi jedną z podstawowych zasad prawa międzynarodowego i prawa traktatów. Przez wieki zdobywała powszechną akceptację, aż w końcu stała się jedną z fundamentalnych norm zwyczajowych w prawie międzynarodowym. Według S. E. Nahlika, uzasadnienia istnienia zasady pacta sunt servanda możemy doszukiwać się zarówno w naturze moralnej, jak i w specyfice prawa czy logiki ${ }^{40}$. Znalazła ona potwierdzenie już w Deklaracji Londyńskiej z 1871 r., gdzie zamieszczono klauzulę, iż „żadne mocarstwo nie może zwolnić się ze zobowiązań traktatu ani zmienić jego postanowień inaczej, jak tylko za zgodą układających się stron, osiągniętą przez przyjazne

37 S. Sawicki, T. Kamiński, op. cit., s. 364.

38 ICJ Reports 1974, par. 36 i 63.

39 J. Białocerkiewicz, Prawo międzynarodowe publiczne. Zarys wykładu, Olsztyn 2005, s. 89.

40 S. E. Nahlik, Wstęp do nauki prawa międzynarodowego, Warszawa 1967, s. 320-321. 
porozumienie" ${ }^{\prime 11}$. Wzmiankę o niej zamieszczono także we wstępie do Karty Narodów Zjednoczonych i jej art. 2 ust. 2, który stanowi, że „dla zapewnienia wszystkim członkom korzystania z praw i korzyści wynikających z przynależności do Organizacji, wszyscy oni powinni z dobrą wiarą wypełniać zobowiązania zaciągnięte przez nich zgodnie z niniejszą Kartą"42. Wreszcie, wspomniana zasada znalazła również potwierdzenie w preambułach obu konwencji wiedeńskich, gdzie stwierdzono, że „zasady dobrowolnej zgody i dobrej wiary oraz pacta sunt servanda są powszechnie uznane”. I dalej, w art. 26: „każdy będący $\mathrm{w}$ mocy traktat wiąże jego strony i powinien być przez nie wykonywany w dobrej wierze". Dodatkowo art. 27 precyzuje, że "strona nie może powoływać się na postanowienia swojego prawa wewnętrznego dla usprawiedliwienia niewykonywania przez nią traktatu". Poprzez akceptację takiego sformułowania $w$ obu wspomnianych konwencjach wiedeńskich, państwa potwierdziły fundamentalne znaczenie tej zasady ${ }^{43}$.

Badając normy funkcjonujące $\mathrm{w}$ prawie międzynarodowym nie należy przyjmować ich absolutnego charakteru, a jedynie skupić się na ich wzajemnej współzależności ${ }^{44}$, ponieważ, jak zauważa A. Poch de Caviedes, ",[...] każda zasada pociąga za sobą inną bądź wiele innych, które ją łagodzą, ograniczają i precyzują. [...] Jedna zakłada zawsze istnienie drugiej, na pozór sprzecznej, która ją łagodzi" ${ }^{45}$. Według $\mathrm{H}$. Waldocka relacje pomiędzy przesłankami wygaśnięcia traktatów a fundamentalną $\mathrm{w}$ prawie międzynarodowym zasadą pacta sunt servanda nauka określa w dwójnasób. Pierwsze stanowisko uznaje owe podstawy za wyjątek od normy pacta sunt servanda, natomiast drugie stwierdza, iż podstawy wygaśnięcia traktatów stanowią normę niezależną, zachowującą jedynie pewne powiązania z zasadą pacta sunt servanda co do celu i funkcji ${ }^{46}$.

Czy jednak klauzula rebus sic stantibus pozostaje w ogóle w zgodzie z tzw. zasadą „świętości umów”, czy też stanowi jej zaprzeczenie? Przede wszystkim należy zauważyć, iż przedstawiciele nauki prawa międzynarodowego nie uznają istnienia zasady wieczystości umów, twierdząc, że każde zobowiązanie, prędzej czy później, powinno przestać funkcjonować. Co do niezgodności normy RSS z zasadą pacta sunt servanda, zdecydowana większość autorów twierdzi, iż taka sprzeczność nie zachodzi. Według nich nie należy przeciwstawiać sobie obu tych zasad. Norma RSS ich zdaniem jest bardzo przydatna,

41 W. Góralczyk, S. Sawicki, Prawo międzynarodowe publiczne w zarysie, Warszawa 2011, s. 80.

42 J. Barcik, T. Srogosz, op. cit., s. 48.

43 M. Frankowska, Prawo traktatów, Warszawa 2007, s. 102-103.

44 T. Jasudowicz, op. cit., s. 17.

45 A. Poch de Caviedes, De la clause 'rebus sic stantibus' à la clause de révision dans les conventions internationales, 1966, s. 163-164.

46 Yearbook of the ILC 1963, vol. II, s. 65-67, 70-90. 
ponieważ pomaga w uzyskaniu swego rodzaju kompromisu pomiędzy elementem dynamicznym i statycznym prawa międzynarodowego. $\mathrm{Z}$ kolei inni autorzy uznają zasadę rebus sic stantibus za logiczną konsekwencję zasady pacta sunt servanda. Co więcej, w nauce uważa się często, iż norma rebus sic stantibus gwarantuje wręcz sprawiedliwe i prawidłowe funkcjonowanie pacta sunt servanda, ponieważ niweluje możliwe jednostronne nadużycia tej zasady ${ }^{47}$. Opozycyjne stanowisko przyjmował wybitny internacjonalista - C. Berezowski, który uznawał, iż przyjęcie klauzuli RSS mogłoby prowadzić do wniosków całkowicie sprzecznych z zasadą zachowania zaciągniętych zobowiązań ${ }^{48}$.

Tak więc na ogół przyjmuje się, iż norma rebus sic stantibus nie pozostaje w sprzeczności z fundamentalną zasadą prawa międzynarodowego, jaką jest zasada pacta sunt servanda. Najczęściej uważa się normę RSS za wyjątek od zasady „świętości umów" bądź też traktuje się je jako normy zupełnie odrębne. Nierzadko również wysuwa się twierdzenie, że klauzula rebus sic stantibus pozostaje w ścisłym związku z zasadą pacta sunt servanda. Jest niejako wkomponowana w jej treść, stanowiąc jej nieodzowną część. Pacta sunt servanda pozostaje więc centralną zasadą, na której oparto ukształtowany w konwencjach wiedeńskich system reguł, gwarantującą stabilizację i chroniącą ład i porządek, z kolei reguła rebus sic stantibus stanowi $\mathrm{w}$ tym wszystkim element pomocniczy, równoważący.

\section{Klauzula rebus sic stantibus w ujęciu prawa międzynarodowego}

\section{1) Zasadnicza zmiana okoliczności $w$ pracach nad Konwencją wiedeńską o prawie traktatów z 23 maja 1969 r.}

Prace nad kodyfikacją prawa traktatów trwały blisko 20 lat, począwszy od pierwszego posiedzenia Komisji Prawa Międzynarodowego, które to miało miejsce w 1949 r. Wreszcie, 23 maja 1969 r. przedstawiciele ponad stu państw (w I sesji udział wzięły 103 państwa, w II zaś - 110 państw) podpisali Akt Końcowy, którego niezwykle istotną część stanowiła Konwencja wiedeńska o prawie traktatów. Nad doskonaleniem wszystkich postanowień Konwencji czuwali wybitni i szanowani brytyjscy znawcy przedmiotu, o których nie wypada nie wspomnieć. Byli to (w kolejności sprawowania funkcji sprawozdawcy): J. L. Brierly, H. Lauterpacht, Sir G. Fitzmaurice, Sir H. Waldock oraz szereg pomocnych im innych członków Komisji. Podjęli się zadania o tyle trudnego, iż w ówczesnych czasach istniał wyraźny podział na Wschód i Zachód, a uniknię-

\footnotetext{
47 T. Jasudowicz, op. cit., s. 19-20.

48 C. Berezowski, Zarys prawa międzynarodowego publicznego, Warszawa 1953, s. 31.
} 
cie współpracy i wspólnej koegzystencji wydawało się niemożliwe. Potrzebne zatem było swego rodzaju narzędzie pomocne przy osiągnięciu takiej współpracy. Narzędziem tym okazał się traktat. Członkowie Komisji stanęli więc przed niezwykle skomplikowanym zadaniem ustalenia, jak właściwie należy postrzegać traktat, jak należy go interpretować i stosować, zawierać, zawieszać i kończyć jego działanie ${ }^{49}$.

Kwestią dyskusyjną stała się zasadnicza zmiana okoliczności. Członkowie Komisji zetknęli się bowiem z kształtowaną przez lata doktryną rebus sic stantibus oraz wieloletnią praktyką państw w tym zakresie, jak również z dotychczasowymi próbami jej kodyfikacji. Podstawę tej doktryny stanowi uznanie, iż każda umowa, którą zawierają państwa, odnosi się do określonych okoliczności i zawiera domyślną (domniemaną) klauzulę mówiącą, że umowa ta traci swoją moc obowiązującą, jeśli nastąpi istotna zmiana okoliczności, w jakich ją zawarto. Nie wszyscy znawcy przedmiotu mający swój wkład w prace nad kodyfikacją byli zwolennikami omawianej doktryny. J. L. Brierly wysuwał twierdzenie, że jeżeli postanowienia traktatowe stają się kłopotliwe do zrealizowania wskutek zmian, jakie zaszły w panującej rzeczywistości, to państwa będące stronami takiej umowy winny razem poszukiwać odpowiednich rozwiązań adekwatnych do panujących warunków. Kładł też nacisk na przestrzeganie zasady pacta sunt servanda. Natomiast H. Lauterpacht nie był przeciwny normie RSS, zwracał jednak uwagę na pewne ograniczenia w zakresie, w jakim można powoływać się na doktrynę rebus sic stantibus, by uniknąć jej nadużywania ${ }^{50}$. W związku z tym pojawiła się konieczność stworzenia swoistej furtki, która dawałaby możliwość zakończenia działania traktatu, który wobec zaistniałych okoliczności nie miałby sensu istnienia, przy czym furtka ta nie powinna godzić $w$ trwałość zobowiązań traktatowych.

Problem ten zauważył G. Fitzmaurice już przy omawianiu kwestii zasady pacta sunt servanda w swoim pierwszym sprawozdaniu z $1956 \mathrm{r}$. Stwierdził on, że zmienione okoliczności mogą być uzasadnieniem dla odmowy dopełnienia zobowiązań wynikających z traktatów „w wyjątkowych okolicznościach [...] i z mocy prawa" ${ }^{11}$. W swoim drugim sprawozdaniu autor poświęcił zasadniczej zmianie okoliczności (określonej w nagłówku również jako zasada rebus sic stantibus) aż trzy następujące po sobie artykuły (21-23). W komentarzu tyczącym się wspomnianych artykułów G. Fitzmaurice doprecyzował, iż wygaśnięcie zobowiązań wynikających z traktatów następuje tylko, gdy w traktacie nie zamieszczono żadnej, wyraźnej lub domniemanej klauzuli odnośnie do ograniczenia jego skuteczności oraz ma miejsce na wniosek jednej ze stron. Dodatkowo, na zasadę można się powołać tylko z uwzględnieniem ściśle określonych

49 M. Frankowska, Konwencja wiedeńska..., s. 24-25.

50 S. Sawicki, T. Kamiński, op. cit., s. 363.

51 Yearbook of the ILC 1956, vol. II, s. 108. 
warunków i ograniczeń. Ograniczenia te wynikać mogą z rodzaju umowy, ponieważ regułę rebus sic stantibus stosuje się co do zasady do umów dwustronnych. W przypadku umów zawieranych wielostronnie, zastosowanie zasady RSS wchodzi $w$ grę jedynie $\mathrm{w}$ razie konieczności i tylko $\mathrm{w}$ razie wycofania się jednej ze stron. Ponadto zmiana okoliczności, na którą zamierza powołać się jedna ze stron, powinna faktycznie odnosić się do traktatu, winna mieć charakter obiektywny, nie może wynikać z działania lub zaniechania którejś ze stron. Oprócz tego musi być nieprzewidziana w traktacie oraz musi skutkować niemożnością wykonania zobowiązań traktatowych bądź też w sposób znaczący zmieniać ich podstawę i dotyczyć okoliczności, które były motywem zawarcia traktatu. Na zaistniałą zmianę powołać się można w ciągu rozsądnego czasu od momentu jej nastąpienia. Zobowiązania wynikające $\mathrm{z}$ umowy wygasają wówczas, gdy nastąpi zgoda stron, bądź na podstawie orzeczenia sądowego lub rozjemczego ${ }^{52}$.

Podobne podejście do stosowania normy RSS zaprezentował $\mathrm{H}$. Waldock w swoim drugim sprawozdaniu z 1963 r. Tytuł artykułu wciąż nosił nazwę "doktryna rebus sic stantibus" i podobnie jak w sprawozdaniu Fitzmaurice'a pojmował omawianą normę jako obiektywną zasadę prawną, niepowiązaną $\mathrm{z}$ wolą i pierwotnymi zamiarami stron. W sprawozdaniu Waldock zaprezentował podejście, iż znaczna zmiana okoliczności, w jakich zawarto traktat, prowadzi do jego wygaśnięcia wówczas, gdy dotyczy ona zmiany okoliczności, które były podstawą umowy. Zmiana ta musiałaby udaremniać dalszą realizację przedmiotu i celu traktatu, jednakże nie może chodzić o zmianę w polityce państwa. Kolejne ograniczenia odnośnie do stosowania normy RSS dotyczyły zmian, które spowodowane były działaniem lub zaniechaniem strony powołującej się na zaistniałą zmianę; gdy strona nie powołała się na zmianę w rozsądnym czasie od momentu jej wystąpienia lub gdy takie zmiany były wyraźnie bądź w sposób domniemany przewidziane w postanowieniach traktatu. W dalszej części rozważań Waldock podkreśla, że na zasadniczą zmianę okoliczności nie można powoływać się w przypadku, kiedy traktat dotyczy transferu terytorium, ustalenia jego granicy lub przyznania praw terytorialnych, jak również nie może odnosić się do aktów konstytucyjnych organizacji międzynarodowych. Według autora sprawozdania, wygaśnięcie następowałoby wyłącznie, gdy zgodę wyrażą strony umowy lub też $\mathrm{w}$ wyniku z góry określonej procedury ${ }^{53}$.

Koncepcja wpływu doktryny rebus sic stantibus na trwanie wiążącej mocy traktatów wysunięta przez $\mathrm{H}$. Waldocka spotkała się z powszechnym uznaniem. Zachowano jej kształt, wprowadzając jedynie nieznaczne zmiany

52 Yearbook of the ILC 1957, vol. II, s. 32-33.

53 Yearbook of the ILC 1963, vol. II, s. 79-85. 
i uproszczenia ${ }^{54}$. Jedna ze wspomnianych zmian dotyczyła konkretnej nazwy artykułu. $\mathrm{Z}$ powodu braku spójnego stanowiska zarówno $\mathrm{w}$ doktrynie, jak i w praktyce państw, zdecydowano o porzuceniu nazwy "doktryna rebus sic stantibus" na rzecz określenia „zasadnicza zmiana okoliczności”. Kluczowe okazało się $\mathrm{w}$ tym względzie zdanie profesora M. Lachsa, polskiego prawnika i dyplomaty, członka Komisji Kodyfikacyjnej, który „wyraził nadzieję, że nagłówek art. 22 (według projektu Waldocka) będzie zmieniony ze względu na negatywne skojarzenia, jakie nasuwa ostatnio doktryna rebus sic stantibus, zarówno prawnikom, jak i laikom" ${ }^{\prime 25}$.

Ukształtowany $\mathrm{w}$ toku dotychczasowych prac projekt artykułu zatytułowanego „zasadnicza zmiana okoliczności” zakładał możliwość powołania się na zmianę odnoszącą się do zdarzenia lub sytuacji, która stanowiła fundament zawarcia danego traktatu przez jego strony i która jednocześnie zmieniała całkowicie bądź znacznie przekształcała istotę zaciągniętych zobowiązań. Wyłączeniu z zastosowania tego artykułu podlegałby jedynie traktat wyznaczający granice oraz powołanie się na zmiany, które zostały wcześniej przewidziane w umowie. Ponadto projekt ustalał, iż w przypadku zmian dotyczących jedynie określonych postanowień traktatu, wygaśnięciu podlegałyby tylko te postanowienia, nie zaś cały traktat ${ }^{56}$.

W późniejszej wersji wprowadzono jeszcze pewne nieznaczne modyfikacje. Założono, że nie można byłoby powołać się na zmianę okoliczności w przypadku traktatów ustanawiających granicę oraz wówczas, gdy wspomniana zmiana spowodowana byłaby przez samą stronę powołującą się, która $\mathrm{w}$ rezultacie naruszałaby traktat lub inne zobowiązania wobec pozostałych stron $^{57}$.

W procesie prac kodyfikacyjnych, państwa miały niejednokrotnie okazję wyrażenia swojej opinii odnośnie do obowiązywania i stosowania normy rebus sic stantibus oraz nadawanego jej kształtu. Przeważnie przedstawiciele państw popierali koncepcję powołania się na normę RSS. Niektóre państwa proponowały korektę o charakterze formalnym, jak np. Japonia, która zasugerowała, że możliwość powołania się na zaistniałą zmianę okoliczności powinna istnieć tylko wówczas, gdy owa zmiana wyrządziła znaczącą szkodę. Poprawce tej zarzucono jednak nadmierny subiektywizm. Kolejne sugestie wysuwały także delegacje m.in. Wenezueli, Boliwii, Maroko, Stanów Zjednoczonych czy Afganistanu. W ten sposób $\mathrm{w}$ toku prac nadano artykułowi dotyczącemu zasadniczej zmiany okoliczności ściślejszą i precyzyjniejszą formęę. I tak, 13 maja 1969 r.,

\footnotetext{
54 T. Jasudowicz, op. cit., s. 156.

55 Yearbook of the ILC 1963, vol. I, s. 135.

56 S. E. Nahlik, Kodeks prawa traktatów, Warszawa 1976, s. 364.

57 Ibidem, s. 364-365.

58 Ibidem, s. 365-369.
} 
na 22 posiedzeniu plenarnym, odbyło się głosowanie zakończone przyjęciem art. 59. „Za" artykułem opowiedziały się 93 państwa, „przeciw” były 3, natomiast 9 państw postanowiło wstrzymać się od głosu ${ }^{59}$.

Podstawę do przyjęcia ostatecznej wersji art. 62 Konwencji o prawie traktatów stanowił więc wspomniany art. 59 z 1966 r. oraz komentarz Komisji Prawa Międzynarodowego odnośnie do zagadnienia wpływu zmiany okoliczności na dalsze obowiązywanie zobowiązań traktatowych. Stwierdzono w nim, że niemal wszyscy współcześni prawnicy, jakkolwiek niechętnie, przyznają istnienie w prawie międzynarodowym zasady, której dotyczy niniejszy artykuł i która powszechnie określana jest mianem doktryny rebus sic stantibus. Pozwala ona na podważenie mocy wiążącej traktatu. Jednocześnie jednak, autorzy podkreślają konieczność wprowadzenia pewnych ograniczeń co do stosowania wspomnianej doktryny, ujmując ją możliwie wąsko i jednoznacznie określając przesłanki, które umożliwiałyby powołanie się na nią, by uniknąć nadużyć. Jest to o tyle ważne, iż nie istnieje obowiązkowy system międzynarodowego sądownictwa ${ }^{60}$. Tak więc zaakceptowany uprzednio art. 59 znalazł się w systematyce Konwencji wiedeńskiej o prawie traktatów z 23 maja 1969 r. jako art. 62 (noszący tytuł „zasadnicza zmiana okoliczności”) w następującym brzmieniu:

1. Zasadnicza zmiana okoliczności, jaka nastąpiła w stosunku do tych, które istniały $\mathrm{w}$ czasie zawarcia traktatu, i jaka nie była przewidziana przez strony, nie może być powołana jako podstawa wygaśnięcia lub wycofania się z traktatu, chyba że:

a) istnienie tych okoliczności stanowiło istotną podstawę zgody stron na związanie się traktatem oraz

b) wskutek tej zmiany radykalnie przekształci się zakres obowiązków pozostałych jeszcze do wykonania na podstawie traktatu.

2. Zasadnicza zmiana okoliczności nie może być powoływana jako podstawa do wygaśnięcia traktatu lub wycofania się z niego:

a) jeżeli traktat ustanawia granicę lub

b) jeżeli zasadnicza zmiana jest wynikiem naruszenia przez stronę, która się na nią powołuje, obowiązku wynikającego z traktatu bądź jakiegokolwiek innego międzynarodowego obowiązku wobec którejkolwiek innej strony traktatu.

3. Jeżeli na podstawie poprzednich ustępów strona może powołać się na zasadniczą zmianę okoliczności jako podstawę wygaśnięcia lub wycofania się $\mathrm{z}$ traktatu, może ona także powołać się na tę zmianę jako na podstawę zawieszenia działania traktatu.

59 T. Jasudowicz, op. cit., s. 162.

60 Yearbook of the ILC 1963, vol. I, s. 80. 


\section{2) Zakres stosowania normy rebus sic stantibus}

Na gruncie nauki oraz praktyki państw, normie rebus sic stantibus przyznawano zakres dość szeroki. Powszechnie jednak zwykło się uważać, iż norma $\mathrm{w}$ obrębie prawa międzynarodowego ma zastosowanie $\mathrm{w}$ odniesieniu do zobowiązań traktatowych. Pojawia się przy tym pewna wątpliwość odnośnie do działania klauzuli rebus sic stantibus. Otóż nasuwa się pytanie: czy ma ona zastosowanie $\mathrm{w}$ odniesieniu do całości międzynarodowego prawa konwencyjnego, czy tylko do niektórych traktatów? Pomocna przy rozpatrywaniu tej kwestii wydaje się praktyka, ponieważ państwa niejednokrotnie powoływały się na zasadniczą zmianę okoliczności w odniesieniu do traktatów, które zawarte zostały na czas określony, bądź takich, które zawierały klauzule rewizyjne bądź denudacyjne. Również nauka skłania się ku poglądowi, że działanie normy RSS obejmuje swym zasięgiem nie tylko traktaty zawierane bezterminowo, ale także te zawierane na czas określony lub posiadające wspomniane już klauzule ${ }^{61}$. Analogiczne stanowisko w tej sprawie przyjęła Komisja Prawa Międzynarodowego ONZ, wyrażając zdanie, że „nie istnieje żaden powód dla rozróżnienia pomiędzy traktatami wieczystymi a długoterminowymi" 62 .

Z czasem pojawiła się też potrzeba rozróżnienia traktatów i zaznaczenia, do których rodzajów norma rebus sic stantibus znajduje zastosowanie. I tak na przykład, zastanawiano się nad kwestią powołania się na normę RSS w przypadku statutów organizacji międzynarodowych. Takie sytuacje miały bowiem miejsce $\mathrm{w}$ praktyce, kiedy to państwo $\mathrm{w}$ celu zwolnienia się z zobowiązań wynikających z takich statutów powoływało się na omawianą normę. Podczas prac kodyfikacyjnych pojawiła się propozycja wykluczenia z zastosowania normy RSS aktów konstytucyjnych organizacji międzynarodowych, ostatecznie jednak zrezygnowano $\mathrm{z}$ tego pomysłu. Wątpliwości budziło także działanie normy rebus sic stantibus $\mathrm{w}$ odniesieniu do traktatów pokojowych, zwykle zawierają one bowiem postanowienia dotyczące zmian terytorialnych. Jednakże nauka dopuszcza ostatecznie powoływanie się na normę RSS w odniesieniu do traktatów pokoju, co potwierdza również praktyka państw ${ }^{63}$. Ważną kwestią było też wyłączenie stosowania normy RSS wobec traktatów granicznych. Podczas prac kodyfikacyjnych delegaci większości państw opowiedzieli się wyraźnie za utrzymaniem tego zakazu. Należy również wspomnieć, iż normy rebus sic stantibus stosuje się wyłącznie $\mathrm{w}$ przypadku zobowiązań, które wciąż pozostają do wykonania na podstawie danej umowy. Oznacza to, że w przypadku

\footnotetext{
61 T. Jasudowicz, op. cit., s. 113-117.

62 Yearbook of the ILC 1966, vol. II, s. 159.

63 T. Jasudowicz, op. cit., s. 117-119.
} 
traktatów już wykonanych norma RSS nie znajduje zastosowania. Kwestia ta wydaje się dość logiczna, ponieważ zobowiązania wynikające $\mathrm{z}$ takiego traktatu już zanikły ${ }^{64}$.

Jeżeli zaś chodzi o podmioty, które mogłyby się powołać na normę rebus sic stantibus, tu także znajdujemy pewne ograniczenia. Chodzi mianowicie o stronę, która poprzez własne działanie lub zaniechanie, naruszyła postanowienia traktatu, powodując lub przyczyniając się do zaistnienia powstałej zmiany okoliczności. W takim wypadku strona nie może się na ową zmianę okoliczności powołać. Takie prawo mają wobec zaistniałej sytuacji jedynie pozostałe strony traktatu. Jednakże co istotne, zmiana, która została spowodowana przez stronę, lecz nie ma charakteru naruszającego postanowień umowy, czyli pozbawiona jest znamion bezprawności, nie zabiera stronie możliwości powołania się na normę RSS65.

\section{3) Przesłanki i następstwa powołania się na zasadniczą zmianę okoliczności}

Konwencja wiedeńska z 1969 r. w drodze wyjątku pozwala uznać umowę za wygasłą bądź daje możliwość wycofania się z niej na podstawie zaistnienia zasadniczej zmiany okoliczności. Powołanie się na wspomnianą przesłankę możliwe jest jednak tylko wówczas, gdy owa zmiana okoliczności spełnia szczegółowe warunki ${ }^{66}$ :

a) ma charakter zasadniczy,

b) nie została uprzednio przewidziana przez strony umowy,

c) okoliczności, które uległy zmianie, stanowiły istotną podstawę do związania się umową przez strony,

d) poprzez zaistniałą zmianę następuje radykalne przekształcenie zakresu obowiązków stron,

e) wykonanie wyżej wspomnianych obowiązków musi wynikać z traktatu i wciąż pozostawać do wykonania (oznacza to jednocześnie, że możliwość powołania się na zasadniczą zmianę okoliczności nie odnosi się do traktatów już wykonanych).

Spełnienie powyższych warunków nie przesądza jeszcze o tym, że w danej sytuacji norma rebus sic stantibus ma zastosowanie. Na zaistniałą zmianę okoliczności, jako przesłankę do wygaśnięcia zobowiązań traktatowych lub wycofania się z nich, nie można powołać się wówczas, gdy:

a) chodzi o traktat ustanawiający granicę,

64 Ibidem, s. 121-122.

65 Ibidem, s. $125-126$.

66 A. Wyrozumska, Umowy międzynarodowe. Teoria i praktyka, Warszawa 2006, s. 452. 
b) zaistnienie zmiany okoliczności było spowodowane naruszeniem przez jedną ze stron, która się na nią powołuje, albo zobowiązania wynikającego z umowy, albo też jakiegokolwiek innego zobowiązania międzynarodowego.

Rozwój i kształtowanie się wszystkich tych warunków i zastrzeżeń następował, jak już wspomniano, stopniowo na płaszczyźnie prawa zwyczajowego. Kwestia ograniczenia zasięgu stosowania normy RSS była jedną z tych, które wzbudzały najwięcej kontrowersji i podlegały najczęstszym dyskusjom podczas toczących się prac kodyfikacyjnych. Jeżeli chodzi o wyłączenie stosowania normy RSS w przypadku traktatów ustanawiających granicę, według komentarza Komisji Kodyfikacyjnej określenie to odnosi się do traktatów, których przedmiotem jest cesja terytorium, jak również do traktatów delimitacyjnych, czyli traktatów dotyczących ustalenia przebiegu granicy państwowej. Wyłączeniu nie podlegają natomiast umowy, które traktują o szczególnych ograniczeniach wykonywania suwerenności, czyli traktaty uwzględniające specjalne zawężenie praw zwierzchnika względem całego terytorium albo tylko jego części ${ }^{67}$.

Zdania co do katalogu ograniczeń były podzielone. Niektóre z państw uważały, iż zakaz ma zbyt wąski zakres i wysuwały propozycje rozszerzenia ograniczeń dotyczących traktatów granicznych również na traktaty uświęcające pokojowe rozstrzygnięcie konfliktu zbrojnego lub ustanawiające konkretny status polityczny dla danego kraju. Natomiast reprezentanci krajów rozwijających się, jak np. Afganistan, podnosili stanowisko, iż zakaz dotyczący traktatów granicznych jest zbędny, ponieważ pozostaje w sprzeczności z prawem do samostanowienia oraz zasadą zachowania pokojowych stosunków pomiędzy państwami. Zdecydowana większość państw opowiedziała się jednak za utrzymaniem dotychczasowej formy zakresu ograniczeń ${ }^{68}$. Takie stanowisko prezentowała też Polska, silnie popierając restrykcje w stosowaniu klauzuli rebus sic stantibus w odniesieniu do traktatów ustanawiających granicę ${ }^{69}$.

Innym dyskusyjnym zagadnieniem w toku prac nad kodyfikacją okazało się sprecyzowanie warunków, które winny być spełnione, by zmiana była uznana za zasadniczą i fundamentalną. Początkowo Fitzmaurice w swoim drugim raporcie wskazywał, że zmiana, która zaistniała, musi być obiektywna w okolicznościach faktycznych, powinna ponadto odnosić się do sytuacji faktycznej lub stanu rzeczy, który istniał w momencie zawiązywania umowy i który stanowił podstawę (motyw) do zawarcia takiej umowy przez jej strony. W konsekwencji zmiana powinna uniemożliwiać dalsze realizowanie celu i przedmiotu traktatu bądź określonych w nim zobowiązań lub też całkowicie zmieniać podstawę

T. Jasudowicz, op. cit., s. 177-179.

68

69

M. Frankowska, Prawo..., s. 159. 
zobowiązania zawartego w tejże umowie. Co więcej, Fitzmaurice podkreślał, iż zmiana taka musi być nieprzewidziana albo niemożliwa do przewidzenia $\mathrm{w}$ momencie zawierania traktatu przez strony ${ }^{70}$. Ostatecznie, pod wpływem toczącej się w tym temacie polemiki Komisja ustaliła, że zmiana taka ma charakter fundamentalny, gdy istnienie takich okoliczności stanowiło istotną podstawę zgody stron na związanie się traktatem oraz gdy skutkiem tej zmiany było radykalne przekształcenie się obowiązków pozostających jeszcze do wypełnienia na podstawie traktatu.

Znaczącą sprawą jest także czas, w jakim państwo może powołać się na klauzulę rebus sic stantibus w odniesieniu do traktatu. W Konwencji wiedeńskiej w art. 45 przewidziano bowiem ewentualność, kiedy państwo może utracić to prawo. Dzieje się tak wówczas, gdy po uzyskaniu informacji o nastąpieniu zasadniczej zmiany okoliczności strona zgodzi się wyraźnie lub w formie dorozumianej, by moc obowiązująca traktatu była utrzymana.

Jeżeli zaś chodzi o skutki, jakie pociąga za sobą zastosowanie normy rebus sic stantibus, chodzi tu głównie o wygaśnięcie mocy wiążącej traktatu oraz zobowiązań z niego wynikających. Jednakże, jak zauważa T. Jasudowicz, skutek prawny zależny jest od rodzaju traktatu, w przypadku którego powołano się na zaistnienie zasadniczej zmiany okoliczności, jak również od postaci samej zmiany. Znaczenie ma bowiem fakt, czy zaistniała zmiana ma charakter trwały i ostateczny czy też przejściowy, czasowy. W nauce generalnie rzecz biorąc, nie uwzględniano zawieszenia działania traktatu jako skutku prawnego zastosowania normy RSS, co najwyżej rozpatrywano ją jako środek tymczasowy przed uchyleniem traktatu. Było to o tyle dziwne, iż w praktyce międzynarodowej państw niejednokrotnie zdarzało się, że strona zawieszała traktat w momencie zaistnienia zasadniczych zmian okoliczności o charakterze przejściowym. Taki przypadek miał miejsce chociażby w 1941 r., gdy Stany Zjednoczone zawiesiły stosowanie międzynarodowej konwencji o liniach ładunkowych, uzasadniając to negatywnymi skutkami zaistniałymi wobec zasadniczych zmian okoliczności ${ }^{71}$. Początkowo również projekty KPM ONZ nie określały zawieszenia jako jednego z rezultatów zastosowania normy RSS, jednakże po uwagach wysuniętych przez niektóre państwa wprowadzono niezbędne poprawki i rozwiązanie takie wpisano w treść ust. 3 art. 62 Konwencji. Nie podlega więc wątpliwości, iż powołanie się na normę RSS skutkuje zwolnieniem od wykonania wcześniej zaciągniętych zobowiązań wynikających z umowy ${ }^{72}$.

Pojawia się jednak pytanie, czy zwolnienie $\mathrm{z}$ uprzednio zaciągniętych zobowiązań odnosi się do wszystkich postanowień (czyli całego traktatu), czy też można powołać się na zasadniczą zmianę okoliczności wyłącznie w od-

70 Yearbook of the ILC 1957, vol. II, s. 62-64.

71 T. Jasudowicz, op. cit., s. 138.

72 Ibidem. 
niesieniu do określonych postanowień. W myśl art. 44 Konwencji wiedeńskiej odnoszącego się do podzielności postanowień traktatów, jeżeli przyczyna wygaśnięcia dotyczy jedynie niektórych jego postanowień, dopuszczalna jest wówczas sytuacja, kiedy wygaśnięciu ulegają jedynie te właśnie rozstrzygnięcia. Jeśli zaś chodzi o pozostałą część postanowień wynikających z umowy, pozostają one wiążące dla stron. Należy przy tym podkreślić, że taka ewentualność jest możliwa tylko wtedy, gdy nie nastąpiło naruszenie sedna zobowiązań umownych pomiędzy stronami i takie postanowienia dają się wyodrębnić od reszty traktatu; przyjęcie tych postanowień nie stanowiło istotnej podstawy zgody innej strony lub stron na związanie się traktatem jako całością oraz wyodrębnienie niektórych postanowień traktatu nie doprowadzi do sytuacji, gdy dalsze jego stosowanie będzie niesprawiedliwe. Wszystkie te postanowienia zostały również sformułowane $\mathrm{w}$ Konwencji wiedeńskiej o prawie traktatów między państwami a organizacjami międzynarodowymi z 1986 r. $^{73}$ Tak więc $\mathrm{w}$ przypadku, gdy zasadnicza zmiana okoliczności dotyka $\mathrm{w}$ sposób bezpośredni najistotniejszych postanowień traktatu, a postanowienia te miały znaczenie decydujące dla jego przyjęcia, wówczas powołanie się na normę rebus sic stantibus winno odnosić się do całości tego traktatu ${ }^{74}$.

Należy przy tym pamiętać, iż KPM skonkretyzowała zasadę, w myśl której nie należy dopatrywać się innych ograniczeń co do skuteczności zobowiązań traktatowych ponad te, które zostały wyraźnie dopuszczone ${ }^{75}$.

\section{4) Norma rebus sic stantibus w orzecznictwie sądów międzynarodowych. Analiza wybranych spraw}

Jak trafnie zauważa T. Jasudowicz, niełatwo jest wysnuć ogólną konkluzję co do stanowiska orzecznictwa odnośnie do uznania treści zasady rebus sic stantibus. Niełatwo również znaleźć sprawy, gdzie wspomniana norma znalazła bezpośrednie zastosowanie. Przeważnie trybunały międzynarodowe, mimo iż nie znajdowały $\mathrm{w}$ podejmowanych sprawach podstaw do powołania się na klauzulę RSS76, nie negowały jej istnienia, uznawały jej obowiązywanie i wiążący charakter na gruncie prawa międzynarodowego. $W$ rozstrzygnię-

73 M. Frankowska, Prawo..., s. 150-151.

74 T. Jasudowicz, op. cit., s. 137.

75 S. E. Nahlik, Kodeks..., s. 371.

76 W sprawie wolnych stref Górnej Sabaudii i Okręgu Gex STSM uznał, że „nie zachodzi potrzeba badania którejkolwiek z zasadniczych kwestii, które pojawiają się odnośnie [do] teorii wygaśnięcia traktatów wskutek zmiany okoliczności, jak np. w jakim zakresie można uważać, że teoria ta stanowi normę prawa międzynarodowego, w jakich przypadkach teorię tę należałoby stosować, gdyby była uznana, oraz jakie metody należałoby wówczas zastosować”. PCIJ, ser. A/B, 1932, nr 46, s. 156. 
ciach wskazywano więc zarówno na zakres, jak i tryb powoływania się na zasadniczą zmianę okoliczności ${ }^{77}$.

\section{Spór między Islandią a Wielką Brytanią w sprawie stref rybołówczych (1974)}

Spór kompetencyjny pomiędzy Islandią a Wielką Brytanią jest przykładem sprawy, kiedy to MTS powołał się na postanowienia Konwencji wiedeńskiej z 1969 r., jeszcze zanim jej postanowienia weszły w życie. Trybunał zaprezentował w nim w sposób bardzo wyraźny swoje stanowisko odnośnie do normy rebus sic stantibus. Odnosząc się do art. 62 Konwencji, MTS uznał, iż stanowi on "pod wieloma względami kodyfikację istniejącego prawa zwyczajowego"78.

Podstawę sporu stanowiły wydarzenia z 1971 r., kiedy to Islandia postanowiła jednostronnie rozszerzyć swoją jurysdykcję $\mathrm{w}$ zakresie rybołówstwa do 50 mil morskich. Swoją decyzję motywowała zaistnieniem zasadniczych zmian okoliczności (postęp w połowach i metodach połowów wywołany nieustannie zwiększającą się eksploatacją żywych zasobów morskich wzdłuż wybrzeży Islandii oraz zmianami $\mathrm{w}$ opiniach prawnych dotyczących jurysdykcji w kwestii połowów). W rezultacie Islandia uznała, że traktat zawarty w $1961 \mathrm{r}$. ( $w$ formie wymiany not) pomiędzy nią a Wielką Brytanią oraz drugi, $\mathrm{z}$ tego samego roku - z RFN uległ wygaśnięciu. Dokumenty te ustanawiały 12-milowe strefy ochronne wokół Islandii, zarezerwowane dla rybaków z tego państwa. Islandia, rozszerzając swoją jurysdykcję w 1971 r., utrzymywała, że wymiana not z 1961 r. nie miała już mocy obowiązującej. Wielka Brytania oraz RFN przyjęły więc opozycyjne stanowisko, sprzeciwiły się działaniom Islandii, a w rezultacie poddały spór pod kompetencje MTS. Oba państwa twierdziły, że traktaty z $1961 \mathrm{r}$. wciąż pozostają w obowiązywaniu, co potwierdzają zamieszczone $\mathrm{w}$ nich klauzule sądowe. Jednakże Islandia zakwestionowała słuszność kierowania sprawy do MTS, podtrzymując tym samym, że umowy wygasły, $\mathrm{W}$ związku z czym takie postępowanie byłoby bezpodstawne ${ }^{79}$.

Międzynarodowy Trybunał Sprawiedliwości w odpowiedzi na stwierdzenie Islandii przyznał jednak, że „zmiany w prawie mogą pod pewnymi warunkami stanowić ważne podstawy do powoływania się na zmiany okoliczności wpływające na czas trwania umowy"80. Zaznaczył też, iż w tym przypadku cel i przedmiot wymiany not z $1961 \mathrm{r}$. miał znacznie większy zakres niż ten, jaki przypisuje mu Islandia. Służyć miał nie tylko rozstrzyganiu roszczeń Islandii wobec jurysdykcji odnośnie do stref rybołówczych, ale także miał zapewniać

\footnotetext{
77 T. Jasudowicz, op. cit., s. 19-20.

78 ICJ Reports 1974, par. 36.

79 A. Wyrozumska, op. cit., s. 453-455.

80 ICJ Reports 1974, par. 32.
} 
środki, dzięki którym strony mogłyby rozwiązywać jakiekolwiek późniejsze spory związane z przedmiotem umowy. W dalszej części MTS przyznał, iż niektóre $\mathrm{z}$ postanowień zawarte $\mathrm{w}$ tych dwóch umowach mogły mieć charakter przejściowy, a więc można je uznać za wykonane, jednakże nie upoważnia to strony czerpiącej korzyści z traktatów do odrzucenia zobowiązań z nich wynikających ${ }^{81}$.

Trybunał, odnosząc się do zasadniczej zmiany okoliczności uregulowanej przez art. 62 Konwencji, zaznaczył, iż zmiana taka musi być fundamentalna, musi godzić w rozwój bądź istnienie jednej ze stron umowy, musi także zwiększać ciężar obowiązków, jakie wynikają z zawartej umowy do tego stopnia, że wykonanie ich byłoby znacząco różne od pierwotnie przewidywanych. W niniejszej sprawie, zdaniem MTS, warunki te nie zostały spełnione, nie ma więc podstaw do zastosowania normy $\mathrm{w}$ tymże przypadku. $\mathrm{W}$ związku ze stanowiskiem podnoszonym przez Islandię, nie można powiedzieć, że zakres obowiązków wynikających z traktatów zawartych w 1961 r. uległ radykalnej zmianie ${ }^{82}$.

Co więcej, w wyroku podkreślono, że doktryna zasadniczej zmiany okoliczności nigdy nie działa tak, że traktat ulega automatycznemu wygaśnięciu bądź pozwala jednej ze stron na jego niekwestionowane wypowiedzenie. Daje jedynie prawo domagania się wygaśnięcia jego postanowień, a jeżeli jest to kwestionowane - do przekazania sporu odpowiedniemu organowi, który zajmie się ustaleniem, czy warunki dotyczące działania zasady RSS zostały należycie spełnione ${ }^{83}$.

\section{Wyrok Międzynarodowego Trybunału Sprawiedliwości w sprawie Gabčikovo - Nagymaros (1997)}

Międzynarodowy Trybunał Sprawiedliwości miał również sposobność omówić warunki zastosowania klauzuli rebus sic stantibus przy okazji rozwiązywania sprawy dotyczącej traktatu zawartego w 1977 r. pomiędzy Węgrami a Czechosłowacją w kwestii budowy oraz działania systemu hydroelektrowni, kanałów i śluz na rzece Dunaj. Jak ocenia M. Frankowska, orzeczenie to jest wyrazem najpełniejszego omówienia zasadniczej zmiany okoliczności dokonanego przez $\mathrm{MTS}^{84}$.

W maju 1992 r. Węgry wypowiedziały zawarty w 1977 r. traktat, w związku z czym sprawę przedłożono do MTS. Państwo powołało się na szereg okoliczności, które łącznie mogłyby stanowić zasadniczą zmianę okoliczności.

\footnotetext{
81 Ibidem, par. 32-34.

82 Ibidem, par. 37, 38, 43.

83 Ibidem, par. 44.

84 M. Frankowska, Prawo..., s. 160.
} 
Chodziło o głębokie zmiany o charakterze politycznym, malejącą efektywność gospodarczą projektu oraz postęp wiedzy w zakresie ochrony środowiska i rozwoju nowych przepisów odnośnie do międzynarodowego prawa ochrony środowiska.

MTS, rozpatrując spór, analizował argumentację Węgier bardziej z punktu widzenia prawa odpowiedzialności międzynarodowej, nie zaś prawa traktatów. Odnosząc się do przesłanek, mogących powodować unieważnienie, zawieszenie czy wygaśnięcie traktatu, stwierdził, że Konwencja wiedeńska o prawie traktatów z 1969 r. ogranicza się do zdefiniowania warunków, w jakich traktat może być zgodnie z prawem wypowiedziany bądź zawieszony; podczas gdy skutki wypowiedzenia czy zawieszenia widziane jako niespełniające tych kryteriów są, w przeciwieństwie do tego, wyraźnie wyłączone z zakresu Konwencji poprzez działanie art. 73. MTS zaznaczył również, iż ograniczenia te są ważne ze względu na zasadę pacta sunt servanda oraz na potrzebę utrzymania stabilności w stosunkach traktatowych ${ }^{85}$.

Odnosząc się do art. 62 Konwencji, Trybunał w rozpatrywanej sprawie uznał jednak, że po pierwsze, klauzula rebus sic stantibus ma zastosowanie wyłącznie do traktatów, które są już w trakcie realizacji. Po drugie zaś stwierdził, że warunki polityczne, jakie miały miejsce w 1977 r., nie były tak ściśle związane $\mathrm{z}$ celem i przedmiotem traktatu, nie stanowiły więc istotnej podstawy zgody stron na związanie się traktatem. Również fakt, że projekt stał się mniej rentowny, niż pierwotnie przewidywano, nie stanowi radykalnej zmiany w zobowiązaniach traktatowych. Podobnie jeśli chodzi o zmiany w stanie wiedzy o środowisku naturalnym i przepisach o ochronie środowiska nie można, zdaniem Trybunału, uznać ich za zupełnie nieprzewidywalne. Ponadto MTS zauważył słusznie, że traktat $\mathrm{w}$ swoich postanowieniach dawał stronom możliwość dostosowania się do tego rodzaju zmian przy realizacji postanowień z niego wynikających, strony powinny zatem podjąć negocjacje, zanim wystąpią z roszczeniem o wygaśnięcie traktatu czy tez wycofanie się $\mathrm{z}$ niego ${ }^{86}$.

Wyraźnie więc widać, że zmiany powołane przez Węgry nie zachowują warunków koniecznych do spełnienia przy zastosowaniu klauzuli rebus sic stantibus ani jako zmiany powołane indywidualnie, ani łącznie, jako zespół przesłanek. Co więcej, MTS zaznaczył jednoznacznie, iż negatywne i warunkowe brzmienie art. 62 Konwencji wiedeńskiej wyraźnie wskazuje, że stabilność stosunków traktatowych wymaga, by zarzut zasadniczej zmiany okoliczności był stosowany tylko $\mathrm{w}$ wyjątkowych przypadkach ${ }^{87}$.

\footnotetext{
85 A. Wyrozumska, op. cit., s. 421.

86 ICJ Reports 1997, par. 104.

87 Ibidem.
} 


\section{Uwagi końcowe}

Do katalogu najbardziej spornych zagadnień w teorii prawa traktatów należy pytanie, czy zmiana okoliczności, jakie istniały w czasie zawierania umowy, może stanowić przesłankę jednostronnego wycofania się, jeżeli zmiana ta ma charakter istotny, nie była przewidywana przez strony i powoduje niekorzystne skutki dla jednego z kontrahentów.

Cezary Berezowski akcentował, że: „Klauzulę rebus sic stantibus uważa się czasem za instytucję powszechnego prawa międzynarodowego. Obrona takiego poglądu jest trudna, prowadzi on bowiem do wniosków rażąco sprzecznych $\mathrm{z}$ zasadą dochowania zaciągniętych zobowiązań międzynarodowych, a oddawanie w ręce państwa stosującego klauzulę oceny, czy nastąpiła zasadnicza zmiana okoliczności, w których umowa międzynarodowa doszła do skutku - może prowadzić do rozstrzygnięć arbitralnych" ${ }^{\prime 88}$.

Jest charakterystyczne, że na rzecz klauzuli przedstawiane są często argumenty, że wychodzi ona naprzeciw potrzebom wynikającym z rozwoju stosunków międzynarodowych i zapewnia niezbędny dynamizm tym stosunkom. Wydaje się, że zatem słuszny jest pogląd, że argumenty te mogą przemawiać wyłącznie za tym, żeby nie zawierać zbyt pochopnie umów bezterminowych, a więc takich, które nie przewidują bezpośrednio możliwości ich wypowiedzenia.

Jednak Konwencja wiedeńska w myśl art. 62 uznała, że zasadnicza zmiana okoliczności może być przesłanką wygaśnięcia umowy lub wycofania się z niej. Zgodnie z przyjętą regulacją muszą zostać spełnione równocześnie określone warunki. Do ich katalogu Konwencja zalicza następujące: zmiana okoliczności jest zasadnicza i nie była przewidywana przez strony; istnienie okoliczności, które uległy zmianie, stanowiło istotną podstawę zgody stron na związanie się umową; skutkiem zaszłej zmiany jest radykalne przekształcenie zakresu obowiązków, jakie na podstawie umowy pozostają jeszcze do wykonania. Należy podkreślić przy tym, że nawet w sytuacji, gdy wymienione przesłanki zostaną spełnione, to na zmianę okoliczności nie można się powoływać w dwóch przypadkach:

1) jeżeli idzie o umowę ustanawiającą granicę państwową; lub

2) jeżeli zmiana okoliczności jest wynikiem pogwałcenia przez stronę, która się na nią powołuje, bądź obowiązku wynikającego z umowy, bądź jakiegokolwiek zobowiązania międzynarodowego.

Ponadto należy szczególnie zaakcentować, że Konwencja wiedeńska tylko wyjątkowo dopuszcza zasadniczą zmianę okoliczności jako przesłankę wypowiedzenia umowy. Przewiduje przy tym w takim przypadku szczególne postę- 
powanie - dział 4 części V Konwencji. Nadal aktualne pozostaje więc pytanie (a nawet zasadnicza wątpliwość), czy postanowienia o możliwości wypowiedzenia umowy ze względu na zmianę okoliczności są słuszne.

\section{Bibliografia}

\section{Źródła i dokumenty}

PCIJ, ser. A/B, 1932, nr 46.

ICJ Reports 1974.

ICJ Reports 1997.

Konwencja wiedeńska o prawie traktatów z dnia 23 maja 1969 r., Dz. U. 1990, Nr 74, poz. 439.

Rozporządzenie Prezydenta Rzeczypospolitej z dnia 27 października 1933 r. - Kodeks zobowiązań, Dz. U. Nr 82, poz. 598.

Statut Międzynarodowego Trybunału Sprawiedliwości, Dz. U. 1947, Nr 23, poz. 90.

Yearbook of the International Law Commission 1950, vol. II.

Yearbook of the International Law Commission 1953, vol. II.

Yearbook of the International Law Commission 1956, vol. II.

Yearbook of the International Law Commission 1957, vol. II.

Yearbook of the International Law Commission 1962, vol. II.

Yearbook of the International Law Commission 1963, vol. I.

Yearbook of the International Law Commission 1963, vol. II.

Yearbook of the International Law Commission 1966, vol. II.

\section{Literatura}

Antonowicz L., Podręcznik prawa międzynarodowego, Warszawa 2011.

Aust A., Modern Treaty Law and Practice, Cambridge University Press 2007.

Barcik J., Srogosz T., Prawo międzynarodowe publiczne, Warszawa 2008.

Bedermann D. J., The 1871 London Declaration, Rebus Sic Stantibus and a Primitivist View of the Law of Nations, "American Journal of International Law” 1988.

Berezowski C., Zarys prawa międzynarodowego publicznego, Warszawa 1953.

Berezowski C., Prawo międzynarodowe publiczne, cz. II, Warszawa 1969.

Białocerkiewicz J., Prawo międzynarodowe publiczne. Zarys wyktadu, Olsztyn 2005.

Bierzanek R., Simonides J., Prawo międzynarodowe publiczne, Warszawa 2004.

Brzozowski A., Wptyw zmiany okoliczności na zobowiazania w prawie polskim (na tle prawa niektórych państw obcych), Warszawa 1992. 
Cahier Ph., Le changement fundamental de circonstances et la convention de Vienne de 1969 sur le droit des traités, [w:] Essays in Honour of Robert Ago, vol. II, Milano 1987.

Cassese A., International Law, Oxford 2004.

Cicero M. T., Pisma filozoficzne, t. 2, Warszawa 1960.

Czapliński W., Wyrozumska A., Prawo międzynarodowe publiczne. Zagadnienia systemowe, Warszawa 2004.

de Vattel E., Prawo Narodów czyli zasady prawa naturalnego zastosowane do postępowania i spraw narodów i monarchów, tłum. B. Winiarski, t. 1, Warszawa 1958.

Domański L., Instytucje kodeksu zobowiązań. Komentarz teoretyczno-praktyczny. Część ogólna, Warszawa 1936.

Ehrlich L., Prawo międzynarodowe, wyd. 4, Warszawa 1958.

Elias O., General International Law in the European Court of Justice: from Hypothesis to Reality?, „Netherlands Yearbook of International Law” 2000.

Frankowska M., Konwencja wiedeńska o prawie traktatów z perspektywy 40-lecia, [w:] 40 lat minęło - praktyka i perspektywy Konwencji Wiedeńskiej o prawie traktatów, red. Z. Galicki, T. Kamiński, K. Myszona-Kostrzewa, Warszawa 2009.

Frankowska M., Prawo traktatów, Warszawa 2007.

Gentilis A., De jure belli. Libii tres, tłum. J. C. Rolfe, Oxford 1933.

Góralczyk W., Sawicki S., Prawo międzynarodowe publiczne w zarysie, Warszawa 2011.

Grotius H., Trzy księgi o prawie wojny i pokoju, w których znajduja wyjaśnienie Prawa Natury i Prawo Narodów, a także główne zasady prawa publicznego, tłum. R. Bierzanek, t. 1, Warszawa 1957.

Haraszti G., Treaties and the Fundamental Change of Circumstances, "Recueil de Cours Académie de Droit International" 1975 - III, vol. 146.

Jastrzębski R., Geneza i znaczenie klauzuli "rebus sic stantibus” w polskim prawie prywatnym, Łódź 2010.

Jasudowicz T., Wpływ zmiany okoliczności na obowiązywanie umów międzynarodowych, Torun 1977.

Klabbers J., Re-inventing the Law of Treaties: The Contribution of the EC Courts, "Netherlands Yearbook of International Law" 1999.

Koeck H. F., The "Changed Circumstances" Clausule After the United Nations Conference On the Law of Treaties (1968-1969), "Georgia Journal of International and Comparative Law" 1974, vol. 4.

Lissitzyn O. J., Treaties and Changed Circumstance, „American Journal of International Law" 1967.

Nahlik S. E., Kodeks prawa traktatów, Warszawa 1976.

Nahlik S. E., Wstęp do nauki prawa międzynarodowego, Warszawa 1967.

Poch de Caviedes A., De la clause 'rebus sic stantibus' à la clause de révision dans les conventions internationales, 1966. 
Pollock F., Spinoza. His Life and Philosophy, New York 1989.

Przybyłowski K., Clausula rebus sic stantibus, [w:] Encyklopedja podręczna prawa prywatnego, red. H. Konic, Warszawa 1930-1935.

Przybyłowski K., Klauzula "rebus sic stantibus” w rozwoju historycznym, „Pamiętnik Historyczno-Prawny", Lwów 1926, t. 3, z. 1.

Sawicki S., Kamiński T., Clausula rebus sic stantibus a zasadnicza zmiana okoliczności jako przesłanka wygaśnięcia traktatu w świetle Konwencji Wiedeńskiej z 1969 roku, [w:] Consul est iuris et patriae defensor. Ksiega pamiatkowa dedykowana doktorowi Andrzejowi Kremerowi, red. F. Longchamps de Bérier, R. Sarkowicz, M. Szpunar, Warszawa: Ministerstwo Spraw Zagranicznych. Biuro Archiwum i Zarządzania Informacją, 2012.

Schwelb E., Fundamental Change of Circumstances, Notes on Article 59 of the Draft Convention on the Law of Treaties as recommended for Adoption to the United Nations Conference on the Law of Treaties by its Committee of the Whole in 1968, "Zeitschrift für ausladisches öffentliches Recht und Völkerrecht" 1969, vol. 29.

Shaw M. N., International Law, Cambridge University Press 2008.

Sozański J., Prawo traktatów. Zarys współczesny, Warszawa-Poznań 2009.

Vamvoukus A., Termination of Treaties in International Law, The Doctrines of Rebus Sic Stantibus and Desuetude, Oxford 1985.

Verwey D. R., The European Community, The European Union and International Law of Treaties, The Hague 2004.

Wharton F., Commentaries on American Law, Philadelphia 1886.

Wyrozumska A., Umowy międzynarodowe. Teoria i praktyka, Warszawa 2006. 